\title{
7 Effects of quality assurance and evaluation on schools' room for action
}

\author{
Galina Gurova, Helena Candido, and Xingguo Zhou
}

\section{Introduction}

This chapter's purpose is to explore the room for action which opens for schools with the emergence of quality assurance and evaluation policies. Other researchers have studied the relationship between schools and policy. For example, Tyack and Cuban (1995) have analysed policy reform and policy implementation in schools; Braun, Maguire \& Ball (2010), Braun et al. (2011), and Maguire, Braun \& Ball (2015) have examined policy enactment in schools; Ball and Maroy (2009) have focused on schools' responses to internal and external conditions; and Falabella (2014) has investigated the effects of accountability policies within schools. Previous research indicates that the relationship between schools and policy is affected by a multitude of objective and subjective variables. Furthermore, "policy ... cannot be reduced to an algorithm ... and the school cannot be reduced to policy" (Ball et al. 2011: p. 637). Finally, there are "discretionary spaces" in schools "in and beyond policies", that is, spaces policy does not reach because of actors' agency (teachers' good ideas or alternative solutions), chance, momentum, or the nature of the object or subject under the policy radar (Maguire, Braun \& Ball 2015: p. 497). The topic is thus far from exhausted.

This chapter contributes new perspectives to the study of school reforms. First, we approach the relationship between policy and schools through the lens of governance theories. As demonstrated in the subsequent section and in the book's other chapters, quality assurance and evaluation (QAE) acts as a means of governance, and in this chapter, we scrutinise the local mechanisms of this governance through evaluation. Second, our investigation of schools' room for action relies on the analytical framework of CADEP (see Chapters 1 and 2; also Kauko 2013; Kauko et al. 2012), which prompts us to view schools primarily as political actors. CADEP postulates that the key to understanding local policy change lies in the analysis of local dynamics: the changing interrelations, intertwinement with different levels, relations between actors and institutions, and the main discursive formations and practices. CADEP analyses three dimensions: the political situation, the political possibilities, and the political room for action. We are primarily concerned with the room for action or the 
potential of actors to exploit existing situations and possibilities, and we use the theoretical frames of organisational analysis and the concepts of economic and symbolic capital to explore schools' opportunities (or lack of opportunities) in respect of QAE.

We start with a description of national QAE policies related to school performance evaluation in Brazil, China, and Russia. These policies create the conditions in which local education authorities govern schools. We then describe local governance mechanisms, which we see as key constitutive elements for creating the room for action of schools as political actors. Finally, we analyse the opening or restricting of schools' opportunities in this room for action. The following questions guide our investigation: 1) How do local authorities utilise QAE in governing schools and why and towards what ends do they use QAE? 2) What are the opportunities which emerge for schools in relation to local authorities' utilisation of QAE?

The following sections present the theories which facilitated data analysis and interpretation of results; a description of the case localities in Brazil, China, and Russia; and a brief overview of national school performance evaluation policies and school-level findings.

\section{QAE in local governance}

QAE has become a strategic governance tool in education politics. Its dynamics are therefore manifested across the globe at different levels, from the transnational to the local (see Ozga et al. 2011). To analyse how QAE is used in local governance, we address three distinctive theories or models of governance which stress QAE in specific ways: 1) the "bureaucratic-professional" model of governance; 2) new public management; and 3) governance at a distance. We briefly describe each in the following paragraphs.

The "bureaucratic-professional" model of governance (Maroy 2008) refers to traditional governance models such as formal communication, labour division, hierarchical position, standardisation, and emphasis on qualification, specialisation, and professionalisation, which are commonly associated with the use of Weber's idea of efficient and rational processes to organise and maintain the social order (e.g., Weber 2015 [1921]). The general claim of traditional bureaucracy is that it is easier to govern rational organisational structures which share the same principles as diverse organisations (see also Weber 1949 [1904]). Conformity to general rules and the equality of treatment are emphasised.

To ensure quality of education in this governance model, the state issues norms, rules, and regulations, and controls the compliance of education organisations and actors to them through such instruments as inspections. Quality of education is understood traditionally in terms of teaching quality, which the state regulates in cooperation with organised education bodies (for example, teacher unions and associations) (Maroy 2008: pp. 15-16). To enhance quality, the state organises standardised teacher training and assumes responsibility for the provision of sufficient inputs in education institutions. 
New public management (NPM) is a term coined in the late 1980s to address the "new" approach to the management of public organisations which is inspired by economic rationalism and business practice (see Hood \& Jackson 1991). Its emergence and propagation were intended to improve public service efficiency by applying private sector management models to public organisations (see Osborne \& Gaebler 1993). NPM applies an entrepreneurial spirit to the public sector, reinforces decentralisation, encourages the use of quasimarket structures for governance, and emphasises control of outputs. Citizens are regarded as consumers and public servants as managers, providers, or suppliers when corporate governance premises are adopted. These "new" relationships in the political arena and public sphere are regulated by accountability regimes and performance management. The latter comprises performance standards and evaluation.

In education, responsibility for outcomes shifts to education "service providers" (schools and teachers), who are guided by national standards. Comparative data and instruments such as "best practices" and rankings orient policymaking. The state incentivises education providers to improve quality with quasi-market mechanisms: the introduction of per capita educational funding, which fosters competition between schools, and the implementation of performance-based salaries and benefits, which increases competition among school personnel. "Consumers" are students and their families, as well as the entire society supporting public education as a common good through taxes. The NPM model of education governance endorses accountability and transparency to make "consumers" aware of the quality of the service delivered by the "providers". This is accomplished through QAE mechanisms such as external evaluations with publicised results assumed to empower consumer choice. The connection of evaluation to performance-based funding and salaries accentuates rational NPM ideas and produces a constant feedback cycle in which outputs feed inputs and vice versa (for a detailed examination of NPM in general education see e.g., Gunter et al. 2016).

The third governance model which we employ in our analysis of local governments' QAE use also emerged in the 1980s. Governance at a distance, as Chapter 6 described in more detail, departs from traditional governance methods (legislation, prohibitions, and regulations) and embraces increased autonomy and self-responsibility (Kickert 1995). This is enabled by reliance on the power of expertise (see Latour 1987) and implies that actors share a significant degree of autonomy based on their will to engage in process and conduct (Miller \& Rose 1990: p. 14). In this paradigm, processes are not always prompted by the centre or government, but by an interrelated network of more or less autonomous actors. The most obvious advantage of such a governance model is that focus on individual agency diminishes the likelihood of resistance to governance measures (Kickert 1995).

QAE procedures contribute to education governance at a distance in several ways. Evaluation schemes produce numerical information, used for comparison and benchmarking, which becomes the key steering tool (Nóvoa \& 
Yariv-Mashal 2003). QAE policies set and enforce standards against which education (education institutions' service, education staff, and education outcomes) is measured, legitimising reward and punishment by government authorities. Additionally, QAE increasingly introduces self-evaluation practices. While these appear permissive and self-initiated, they need to comply with standardised indicators and central regulations. All these policies and practices implicitly emphasise constant self-regulation and self-improvement (Lawn \& Grek 2012: p. 146). Ball (1993: p. 111) suggests "constraints are replaced by incentives", "prescription is replaced by ex-post accountability based upon quality or outcome assessments", and "coercion is replaced by self-steering [under] the appearance of autonomy". Another way QAE enhances governance at a distance is provided by education outcomes in a variety of rankings, ratings, indicators, and reports. These are publicised and often prepared by the media with the purpose of modulating the decisions and actions of students and their parents (e.g., Lingard et al. 2016).

\section{Schools as political actors}

We see schools as political actors because they possess at least some degree of political power, which enables them to influence education decisions, policies, and outcomes. Thus, our analysis of schools' room for action is informed by the political frame of organisational analysis (Bolman \& Deal 2013). This lens facilitates the interpretation of local data, since it enhances understanding of the ways in which schools utilise QAE policies to gain power and resources. Within the political frame, education can be viewed as an ecosystem in which schools adjust to external pressures and interact with other ecosystem constituents (local education authority bodies, families, and commercial providers of education services) to obtain resources. Bolman and Deal (2013) refer to the different resources required by any organisation, such as time, money, and attention (p. 26) and describe the internal resources connected to an organisation's personnel: people's skills, attitudes, energy, and commitment (p. 117).

Bolman and Deal (2013) outline multiple sources from which organisational actors can obtain power and influence, which are also necessary in the struggle for resources. Identifying such sources is useful to an analysis of the political interaction between education authorities and schools. For example, local government authorities can be viewed as possessing a coercive power based on the ability to legitimately constrain, prohibit, interfere, or punish. Local authorities' power may also be based on the control of rewards - the ability to deliver jobs, money, and political support. Concomitantly, schools may draw influence from other sources, in particular, from their expertise and reputation, alliances and networks, and control of agendas (for a more detailed description of sources of power see Bolman \& Deal 2013: pp. 225-242).

To broaden the perspective of the resources schools can gain through QAE policies, we use the concept of material and symbolic benefits, which stems from the distinction between economic and symbolic capital (see Bourdieu 
1984 [1979]; Bourdieu 1998 [1994]). Bourdieu (2013 [1980]) argues that economic and symbolic capital are inextricably combined in the social space; one complements and reinforces the benefits of the other. The material benefits schools can obtain through QAE policies are easier to track and measure, because in most situations, they are connected to government budgets or domestic aid programmes. At the same time, not only do individual interests lie in the material order, but individuals and organisations aim to enhance symbolic dispositions, such as prestige, status, and honour, in acting in the social space (Pinto 2000). The value of symbolic benefits arises from the recognition (perception, understanding, and assurance) of relationships established between those who possess and utilise symbolic capital (Pinto 2000). Symbolic benefits can be obtained from a wide constellation of sources. For example, the achievement of a top-ranking position in league tables or awareness (through advertising or other marketing campaigns) of good scores in standardised evaluations can afford valuable symbolic benefits to schools.

\section{Case localities}

Our data were collected in selected localities in each of the case countries through document analysis, interviews, and observations (details on data collection and analysis are provided in Chapter 2). Given the data collection methodology, our findings are not representative of the countries or localities in which our research was undertaken. We aim to reveal the diverse mechanisms of QAE policies' influence and to understand the logic and interests of schools concerning performance evaluation mechanisms. However, when analysed comparatively, the perspectives of local education practitioners reveal similar patterns which are arguably meaningful for a more general analysis of schools' room for action.

In Brazil, the data were collected in the southern state of Santa Catarina (population 6.4 million). The state's social indicators are among the highest in the country and across Latin America. Its prosperity derives from its diversified and industrialised economy. We selected Santa Catarina for our research because it has been especially active in the introduction of QAE policies. It is the only Brazilian state to order a report from the Organisation for Economic Cooperation and Development (OECD), and the 2010 Programme for International Student Assessment (PISA) recognised Santa Catarina as the leader in Brazilian QAE. Since 2005, Santa Catarina has attained the highest IDEB (Index of Basic Education Development) of all Brazilian states. Interviews and observations were conducted in three large public schools (each with around a thousand students and fifty teachers) and in key state and municipal education organisations.

In Russia, we conducted our local study in the Republic of Chuvashia (population 1.3 million), which is approximately 650 kilometres from Moscow. Chuvashia is representative of mid-size, middle-income regions, with about half its population of non-Russian ethnicities. The region has a 
well-developed QAE system which has received positive reviews from external evaluators and is often presented as an example of best practice at training sessions for QAE professionals (Bochenkov 2013). The World Bank guided the education reforms implemented in the republic. Our local case from Chuvashia is Cheboksary, a city of half a million and the capital of the republic, as well as the centre from which all regional QAE initiatives originate. We collected this chapter's interview and observation data primarily from two public schools in the same city district, as well as from municipal education organisations.

Local data collection in China followed a different pattern because of schools' restricted accessibility. Intensive school observations were not allowed, so our analysis relies solely on data from interviews with school principals and deputy principals conducted in seven schools from two provinces in Northern China. One province belongs to a well-developed region. New education reforms are being piloted and tested in the locality, making it one of the most advanced areas in adopting national QAE policies. The other, situated on the coast, can be described as moderately developed, with an income level slightly above the Chinese average. Although it has a reputation for producing competitive students, it is neither labelled nor known in China as the most active or pioneering in innovating and implementing education reform. While the process of QAE policy introduction varies across different provinces, here the policy has been adopted moderately quickly. The schools visited in the two provinces varied greatly in their history, ranking positions, and student bodies. We conducted interviews at different types of schools with the goal of obtaining greater diversity in interviewees' positions and opinions.

\section{The rise of school performance evaluation in Brazil, China, and Russia}

In each country, new evaluation instruments measuring students', schools', and teachers' performance have recently been added to the traditional QAE system (Chapter 3 discussed the development of national QAE systems in detail). In Brazil, such performance evaluation instruments are the SAEB (Basic Education Evaluation System) and the IDEB (Index of Basic Education Development); in Russia, they are the national examinations (GIA), which assess students' education outcomes after grades 9 and 11; in China, they are the NAEQ (National Assessment of Education Quality), which assesses students' academic achievement in grades 4 and 8 .

Education statistics - or the "school census" - in Brazilian education began in 1931. The collection of statistics was gradually decentralised to the Brazilian states, which then sent a compiled data set to the federal government. The SAEB was introduced in 1990. It consists of two principal biannual assessments of maths (problem solving) and Portuguese (reading), one involving a sample of pupils in both primary and secondary schools, the other applying to all pupils in public schools registered in grades 5 and 9 and popularly known as Prova 
Brasil. SAEB results are used in calculating the IDEB, alongside school flow data (progression, retention, and dropout rates) provided by the school census. This indicator was created in 2007 to measure the quality of each school, municipality, and state and the overall quality of national education.

The SAEB is claimed to contribute to the improvement of education quality and the universalisation of school access by subsidising policy formulation, reformulation, and monitoring (INEP 2016). It is intended to enable a better understanding of the variables which influence pupils' performance. The SAEB is also intended to increase participation of parents and society in education (Brasil 1988, 1996, 2007, 2014). Finally, researchers envision the SAEB as an instrument to enhance local education management at sub-national levels (Machado \& Alavarse 2014).

The SAEB and IDEB are national policies. However, Brazilian states and municipalities, which are the country's major providers of public education, have the autonomy to develop their own student performance evaluations, and use them differently for simple comparison, diagnosis, school and staff accreditation, and performance-based remuneration. Around twenty states (Brooke, Cunha, \& Faleiros 2011) and more than 1,500 municipalities (Bauer, Pimenta, Horta Neto, \& Sousa 2015) coordinate a standardised evaluation in addition to the SAEB. All evaluation mechanisms in primary and secondary education, except for university entrance examinations (vestibular and ENEM), are low-stakes.

In 2007, however, the school census started to investigate student and teacher data, comprising data about school infrastructure, docents, enrolment, school hours, and school flow by level, stage, and type of education. The school census is a reference for calculating public school funding as well as for managing several federal programmes. Besides being responsible for the collection of these reports, the principals of several Brazilian public schools are also accountable for the fulfilment of action plans derived from management projects they presented when they were elected.

In China, education supervision comprising administrative and education inspections plays a major role in school quality assurance as a sub-system which complements local education governance. The supervision service collects statistical information on schools and ensures that education policies and plans are implemented by schools as expected. Local governments provide schools with funding, salaries, in-service training, and promotion for school staff based on this information.

In 2007, China introduced a new national assessment of education quality (NAEQ), employing standardised testing as a supplement to education supervision, which resembles international large-scale assessments, such as PISA, and Trends in International Mathematics and Science Study (TIMSS) (NAEQ 2015). The NAEQ evaluates students' achievement in Chinese, mathematics, and science. It also includes indicators of students' physical and mental health and socio-economic conditions. Assessment results are accumulated in a national database to inform policymaking. Performance data are also circulated 
among local education actors. The report is delivered by the NAEQ's national centre to avoid different provinces or localities competing with each other, and it aims to provide comprehensive information to policymakers so they can learn the real level of educational development and problems in schools. The performance report is sample-based, and since 2015, all Chinese provinces and municipalities have received an annual assessment.

As China has a long history of ranking the quality of education with examination scores or other administrative methods, this new model of testing, along with the popularisation of student-centred pedagogy, is expected to use quality evaluation to reduce ranking and ruthless competition in schools. China's ten-year blueprint for education development between 2010 and 2020 (State Council 2010) outlines the central government's intention to renew and upgrade evaluation practice at all levels. Nevertheless, at the local level, school quality is largely defined by students' examination scores, which determine their opportunities to enter the next education levels. The scores thus remain parents' primary concern.

In Russia, the traditional instruments of quality control in school education are inspections and school reports. Until 2009, school-leaving examinations were conducted by each school, supervised by the local education authorities. Examination, end-of-quarter, and end-of-year grades served as the main indicator of students' educational achievement. Policymaking was also informed by statistical information on school facilities, teacher qualifications, and student numbers. These data and grades assigned by schools are still included as indicators in the quality evaluation system. However, they are complemented by data from diverse large-scale assessments of student achievement and largely from national examinations.

National examinations were introduced in the 2000s as a key element of the newly developed system of evaluation and quality control in education. Their introduction was a way to ensure the "unity of educational space" across the diverse country, and at the same time, these standardised tests were to produce statistics on education quality for more informed policymaking. Finally, at the time of its introduction, the national test was acknowledged as a strong measure of equality and quality improvement (Bolotov 2004).

The Unified State Exam (USE, or GIA-11) is sat on completion of the eleven-grade school education, and the State Final Attestation (SFA, or GIA-9) is undertaken in grade 9, the last grade of general education. Examinations test graduates' knowledge in two compulsory subjects (Russian and mathematics) and several chosen subjects. Passing the tests is necessary to obtain a graduation certificate and apply for the next level of education. Contents of the tests are developed independently of schools in connection with the compulsory state curriculum. Scores in both tests serve as the main indicators of education quality in national and regional policy documents on quality assurance, school rankings, teacher performance evaluation metrics, and even (until 2015) assessments of regional administrations' effectiveness (Piattoeva 2015). Thus, national 
examinations carry high stakes for all involved in education: students and parents, school workers, and the education authorities.

\section{Local governance of schools through quality evaluation and assurance}

The room for action of schools as political actors is conditioned by local education authorities' use of evaluation procedures. In each of our case localities, diverse control and governance measures are applied to schools based on performance. In considering the whole range of traditional and new QAE procedures implemented in each locality, we focus on developments in local governance models inspired by the introduction of performance evaluation instruments. Our data analysis was informed by the three theoretical models of governance described at the beginning of this chapter; our interviewees' specific accounts or other indicators in our research data caught our attention, because they were characteristic of a particular governance model. At the same time, we sought to reflect the complexity of local governance realities in our findings, not limiting them to models but enriching the understanding provided by a combination of the three theoretical devices.

The governance practices this section describes are those mentioned by our respondents, presented in the local policy documents we analysed, or which we observed in the localities. Hence, "Brazil", "Russia", and "China" in this section simply label the source of data and should not be taken to imply that the attributed governance practices are consistent across the countries.

\section{Evaluation as an indirect intervention}

In accordance with national discourses on evaluation and quality improvement, by introducing new evaluation procedures, local authorities seek to change school management and teaching methods without direct interference. Evaluation is regarded as a means of reorienting school staff to different aims more aligned with national education priorities and encouraging school management and teachers to devote extra effort to improvement. In all observed localities, schools were required to regularly produce specific documents in which they declared their goals and evaluated their progress (in Brazil this was labelled "action plans"; in China, "self-regulation"; and in Russia, "self-evaluation reports" and "plans for the improvement of the effectiveness of learning"). In other words, local authorities use QAE procedures to ensure and stimulate schools' self-improvement, based on the assumption that schools would probably not do this on their own.

Both the internal evaluation process, which requires an action plan, and the external evaluation process should demand action plans in order to overcome the appointed limitations and difficulties ... We want to make schools commit to start discussing evaluation, discussing self-evaluation, 
its own resources, what is more important, what is better, ideal, because if nobody discusses anything, nothing will be taken into account, and hardly anybody will do it. School management, for instance, has a huge commitment and in the end, induces this. In case it doesn't, everything gets very loose ... And that's how the human being is ... The teacher lets the routine get loose, students also get loose ... [when the teacher] does not demand, does not require people to take some position ....- then we know [what happens - a pessimistic scenario results].

(BR-S-11)

Attention is paid to school staff's ability to work with data. By training teachers to produce and analyse evaluation data, authorities expect them to become better informed of their students' learning gaps and to close them more successfully:

A teacher should be able to work with feedback, which means to do tests, to encourage advanced learning ... The problem is how to know, or, rather, how to influence what happens in the classroom, because the teacher needs to know what he or she is teaching.

(RU-M-2)

Stimulation of the production and management of data in schools is intended to improve staff's reflexivity and critical thinking and direct their attention to problems the authorities deem important. For example, a Russian interviewee said that one of the aims of evaluation was to make schools pay more attention to low-performing students (RU-M-2). In China, it is hoped that new evaluation will loosen the current overarching emphasis on examination results and redirect attention to students' well-being in schools and in their general learning context (State Council 2010). Evaluation is perceived not simply as a new tool but as a new way of thinking, an "evaluation culture" (BR-S-11), which should permeate schools' main practices, from planning and managing to classroom practice.

We have documents and bulletins that are specific to the principal, which give him a different view in relation to these indicators. We have bulletins for teachers, and there is one that students take home to their parents ... We invite 150 professionals to participate in workshops because we want them to be able to get all the knowledge, not only know how to read a Prova Brasil result, but to make them qualified to do a specific analysis of the results, and willing to know the indicators ... Our main objective is to strengthen this view, to enlarge this view and to make them gain more benefit from what is available today.

(BR-M-2)

We have never thought that context indicators can be used, for example, to introduce some new things, to form new administrative structure in 
schools, for example. [In schools] they are already interested to ensure that information is collected, so a [special] deputy principal is appointed who supervises evaluations ... Also new deputy principals for primary education are appearing. Previously, not all schools had them, but now there are all-Russia tests [vserossiiskie proverochnie raboty, national tests at the primary level], so there is a new [administrative position].

(RU-M-2)

Some of our interviewees from schools in Brazil and Russia expressed scepticism of the authorities' declared intention to foster improvement in schools. They regarded the "improvement through evaluation" discourse as a disguise for the authorities' real intention, which was to shift all responsibility for quality to schools and teachers. Numbers inadequately represented quality of education, school actors explained, and if the authorities were sincerely concerned about quality and the situation in schools, they would "come and see" instead of calculating indexes. This view was shared by an interviewee from the Russian local authorities:

When schools submit reports, [numerical] analysis, we still look at ... what problems reveal themselves [in these reports]. We understand that we need to go and visit these educational institutions, we should see and help them in this respect ... After national examinations we worked through all [identified problematic] issues with every [school] administration, we created a whole schedule of meetings with administrations, yes, we worked overtime for a week with our schools, discussed where the gaps are in those institutions, what to do to eliminate the gaps.

(RU-M-1)

This illustrates that authorities question the adequacy of data and numerical evaluation tools for quality assurance. The next section explains in more detail how evaluation is connected to other governance instruments.

\section{Justification of reward and punishment}

School inspections based on performance evaluation were common in our observed localities in China and Russia and are under discussion in Brazil. The functions of such inspections include identifying problems contributing to unsatisfactory school performance, demanding schools develop plans for improvement, and in some cases, applying sanctions. In Russia, inspections are authorised to issue fines and even suspend school licences. In China, schools' failure to meet performance standards may also have severe consequences. A first failure means the school will be disqualified from annual rewards, and a principal's promotion may be deferred. Teachers may lose the opportunity to pass their annual appraisal and gain promotion. If a school continues to fail within a given time, it may be suspended or closed. However, such extreme 
decisions are very rare and usually apply to "low-quality" schools. In public schools in both China and Russia, the principal's suspension is another potential consequence if the school consistently underperforms. Although such harsh measures prescribed by inspectors are relatively rare, the possibility of such measures places great pressure on schools to avoid poor results in performance evaluation. Inspection itself can function as a form of punishment or threat, even when high stakes for school administration are not attached to it, which we witnessed in Brazil.

Respondent: If there are some problematic issues, they need to be identified, to be demonstrated.

Interviewer: And what support was offered to schools that had many problems? Respondent: Well, there were not many of them, in practice ... In some, the directorate was changed (RU-M-2).

Nobody wants to receive the external commission, which is a commission created by the [sub-national authority] that goes to the school to check what led to a low IDEB in that school ... This process will induce everyone to grow, everyone to increase [IDEB], always, because nobody wants to have the thirty lowest [IDEB scores and be inspected].

Performance evaluation also facilitates governance through diverse mechanisms which link evaluation results to provision of resources. First, evaluation can justify distribution of funds, including performance-based funding and salaries, project funding, and grants. Salaries of Russian school administrators and teachers contain a performance-based element. In the Russian case, locality students' GIA results are also considered in school and teacher contests and as criteria for participation in special projects involving extra funding.

We had an indicator connected to student absence in schools. Currently we still have it, but then we made a specific emphasis on it, we made [schools] watch these numbers more attentively. It was our goal to stimulate them with this criterion so that they would improve the situation. For example, if her or his salary depends on the improvement of this indicator, then ... there is a motivation for the manager to work on it.

A Russian school principal reports,

The municipal Department of Education demands a certain percentage [of high grades which the school students need to obtain]. If we do not provide the required quality, it means that we produce pedagogical defects. Our funding is decreased then.... We could not even apply for some 
grants, because only schools without students with a criminal record could apply, and we have such students.

In Brazil, high performance is not the only route to resources, as there are also national and sub-national government programmes for providing lowperforming schools with financial and technical support. Bonus funding to high-performing schools in some Brazilian regions is provided to reward staff performance, and some schemes function under which high-performing schools become sponsors and advisors of low-performing schools to improve the local education system's overall performance. In China, different localities have different traditions of encouraging schools to achieve better results in college entrance examinations. An interviewee reported of certain localities, "They give a bonus to some schools depending on how many students are recruited by Qinghua University or Peking University, or how many students are recruited by top universities" (CN-P-01).

In Russia and China, performance evaluation results count in awarding qualifications and honoured status to administrators and teachers. In Russia, professional qualification and status influence salary levels and are also crucial for professional recognition. In China, they are not connected to remuneration, but as symbolic rewards, they are highly valued, as a Chinese school inspector explained,

The punishment of a teacher who, for example, failed the moral evaluation, is that he or she cannot participate in teacher promotion in this year; he or she would not participate in the selection of honoured teachers. This is quite a severe punishment for a teacher. Think about that, if as a teacher you could not get promoted or become an honoured teacher because of a moral problem, how can you gain trust from students and parents?

(CN-S-05)

In all three case countries, low-performing schools are offered support in the form of supervision and training for teachers or peer assistance in teaching. However, some interviewees from schools regarded this practice not as support for teaching methods but as symbolic punishment, which labelled such schools and teachers as incompetent.

They [the local authorities] came up with a very "interesting" project. For example, one subject teacher in our school got six fails in GIA results [six students from his/her class failed in the subject examination]. And this class is to be visited by another teacher who had no fails, so that he/she can conduct the preparation-for-GIA lessons with the students of this class. What is the implementation of this project going to demonstrate? That this teacher [the one who had fails] did not do his/her work, and another lady now comes - oh so smart, look, children! So, what image of this class's 
teacher is this project going to create? Do they think of it at all? And this [intervention by a different teacher] is not going to work, in just one week, because students do most for the teachers they know and love.

(RU-SM-4)

The practice of using performance evaluation as justification for reward and punishment does not always mean that authorities implement evidence-based policy. Sometimes decisions about reward or punishment come before evaluation results, which are subsequently used as justification for decisions. This mainly concerns evaluations in the form of inspections but is sometimes applied to numerical performance evaluations. A Russian interviewee told us that a ranking based on numerical indicators was considered inaccurate by a supervising authority because it contradicted the authority's opinion of who should occupy the top of the ranking:

Last year we tried to rank administrators based on the indicators given by the [regional] Ministry [of Education] ... This was ... even a small argument, you couldn't call this a conflict, but just an argument about "why you have chosen the wrong school [as ranking leaders].

(RU-M-2)

In Brazil, some school interviewees perceived that evaluation criteria had been developed to accommodate political interests and produce better results.

I see that the main role of external evaluation is to manipulate indexes, manipulate a situation so public schools look as if they ... have good conditions. I see that there is a clear lowering of education [standards] in public schools, and this [is] veiled [by politicians, otherwise they will not be elected] ... That's when the index is essential.

(BR-MS-1)

\section{Accountability of authorities}

Local authorities themselves are subject to evaluation and sanctions because they occupy an intermediary position between schools and the sub-national and national levels. Local officials need to demonstrate that they are successfully implementing national and sub-national regulations and doing something about schools' identified problems. In other words, local authorities undertake evaluations to report to their own supervisors.

Since 2009 we have established a notification system of supervision results. The results [are] included as one of the main indicators of the county government performance to offer evidence for reward or punishment ... Moreover, the problems that have been found in a previous inspection will be put into the special checking list [for] next year.

(CN-M-02) 
It is therefore in local officials' best interest to ensure that schools pass inspections. A Russian interviewee reported,

Supervision authorities visit [schools] quite often, be it [the] prosecutor's office or the Department for Supervision and Control in Education. They take a certain aspect and review it. But before they visit I have already assigned a specialist for this task; she goes in advance and, together with the school, checks all the documents. [She] also observes lessons, because sometimes there are [federal] tests in different subjects. She, so to say, prepares schools for these inspections. And when the Department for Supervision and Control comes, she is there with them and polishes (otrabatyvaet) certain issues.

(RU-M-1)

A Chinese respondent explained that the need for local inspections arose from other evaluations:

Lots of evaluation of schools is still based on school [graduates'] performance in college entrance examination results. Schools might go to another extreme to [devote] all the time to the examined subjects. Many schools don't even teach the subjects not tested. So, supervision makes sure that no such actions happen in schools.

(CN-S-01)

With the lack of supervision and inspection in Brazil, sub-national governments tend to use teacher training to ensure the curriculum has been followed and the evaluation culture has spread.

Local authorities are also accountable to the public, especially parents, so authorities use QAE instruments to demonstrate their work and schools' quality to the local community. At the same time, evaluation serves as a means by which authorities involve community actors in the governance or support of schools. For example, both Brazilian legislation and public opinion call for the participation of community and families in education and, in a context of high social inequality, voluntary work and donations often target low-performing schools. The authorities thus view evaluation as a tool to provide relevant information on schools to the community; evaluation needs "to reflect the reality of education ... [and] raise [the] involvement [of community members in] schools" (BR-S-9). In Russia, some local quality assurance measures, including inspections, are implemented in response to parents' complaints. Self-evaluation reports prepared by Russian schools are also published to provide parents and the public with information about school quality. Chinese interviewees also mentioned that evaluation and inspection in some localities involve parents, the district community, and the media: "We [inspectors] interview students and parents, and then the community around the school. We also view the school archives, and then assess the implementation of rectification, [and] do [a] follow-up investigation" (CN-M-01). 


\section{Schools' room for action in QAE}

Local authorities' use of QAE in Brazil, China, and Russia to govern schools sets schools' room for action in their localities. Remembering the aims and actions of authorities described in the previous section, we now proceed to an analysis of school administrators' and teachers' reactions. In this section, we seek to answer our second research question: what are the opportunities which emerge for schools in relation to local authorities' utilisation of QAE? We look at schools' opportunities as political actors - their opportunities to obtain power and resources. For this analysis, we employ the typology of the sources of power (Bolman \& Deal 2013), which emphasises the diversity of such sources (or kinds of power). We consider not only material but also the symbolic resources schools can obtain, and focus on both those who gain and those who lose power and resources because of changing QAE policies.

\section{Evaluation as an internal management tool}

Some school administrators in Brazil and Russia eagerly embrace evaluation as an effective management instrument. They see comparison as a "natural way of human thinking" (RU-S-3 and BR-SS1) and use both traditional and new evaluation tools to encourage their teachers, students, and parents to work harder to get better results. Schools can refer to evaluation data at staff meetings to set goals for the upcoming period, identify student groups requiring extra attention, and praise high-performing teachers and scold low-performers. One of the Russian schools we observed organised an internal ranking of teachers based on their students' performance and regularly designed contests for students and staff members.

The internal quality control [vnutrishkol'nyi kontrol', a traditional procedure involving regular lesson observations and peer discussions] is the main thing! I always tell deputy principals: you can postpone anything, but do the internal control! One should reveal a problem in time and solve it quickly, then you will have good quality in the end. For example, in one grade 8 group students suddenly started getting fail marks. It turned out that their former teacher worked insufficiently, and the deputy principal didn't find it out in time. So, I went teaching ... that group, we cleaned a little bit ["cleaning" means getting rid of low-performing students, primarily by persuading them to transfer to another school], and in grade 9 they passed national examinations more or less satisfactorily, though there were still five fails in that ... group.

(RU-S-1)

When I see the IDEB, the first thing I do is to compare my school with others - I use all data... . I compare with other schools ... [in the neighbourhood] in order to understand, because the region has similar socioeconomic characteristics, so we can compare. This is natural and for me, 
indexes, numbers, they have a meaning ... I always use the indexes in the beginning of [the] school year in our pedagogical meetings. One of the first things I do is to show the indexes. Both the IDEB and other general indexes and government measures, as well as our internal indexes, retention, and dropout indexes, and what we will do in order to keep students at our school.

(BR-SS-1)

In China, our respondents mentioned various school initiatives such as the creation of extracurricular classes which were launched to gain additional scores in external evaluations. We witnessed no example of the appropriation of new QAE tools for internal school purposes.

\section{Schools' room for action in relation to resources}

The connection between evaluation results and resource distribution allows some schools and school workers to benefit from the new QAE system. Some interviewees said that students' high performance could secure the performance-based element of a salary (in Russia and in some Brazilian localities) and the obtaining of higher qualifications (in Russia and China). Low performance was perceived by our Russian and Chinese respondents as a potential threat to securing necessary funding, which we did not observe in Brazil, where low performers tended to receive assistance rather than punishment. Although Brazilian schools can obtain resources if they perform poorly in evaluation schemes, maintaining low scores in national and sub-national standardised tests is far from becoming a strategy for such schools to supply their needs. In Russia, where examination results carry high stakes for students, schools can also attract additional financial resources by offering exam preparation classes for a fee.

The principal very actively encourages additional paid-for classes. In grades 9 and 11 they are not really voluntary, and in other grades they are also strongly recommended to students, because it is very important for the school budget.

(RU-S-26)

Schools' high performance also indirectly creates opportunities to obtain better resources. First, it helps to attract better teachers, because salaries, career development, and reputation depend on performance evaluation results. It also helps to attract performance-oriented students. In Russia, schools receive per capita funding, so having more students is financially beneficial. This also applies to non-public schools in China ("non-public" includes expensive private schools and cheaper non-government schools, such as Minban schools):

School reputation is very important to us. Even if there were no inspection from the government, we would still do our best to improve quality 
because unlike public schools, our lives ... [depend] on students and how many students come here.

(CN-MBS-01)

\section{Reputation and influence}

School performance is converted into school reputation through unofficial media rankings (in all three countries), public self-evaluation reports (in Russia and China), and participation in contests and projects conditioned by performance (in all localities). A good reputation is itself valuable, as was frequently emphasised by our Chinese interviewees. It also motivates school personnel and students. A Russian teacher explained why high performance in examinations was important: "It is our school's prestige, and parents expect it from us, and my reputation in the city - I want to support it, not to lose it" (RU-S-27). Creating a good reputation and visibility is a long-term strategy to attract resources and influence:

You [as a school] should participate in contests, be visible, so that they [the authorities] see you, remember you afterwards. There are contests such as "Teacher of the Year" - we cannot hope to win ... those. But there are so many different contests, you can find one that does not depend on results [of students so much], in which you can win, if you read the criteria attentively ... Piloting [of federal or regional educational initiatives] - they [the authorities] don't give it to any [random] school. And if a school participates in piloting, if it organises city and regional seminars - the teachers [of this school] can then mention it in their qualification documents or in grant applications.

(RU-S-4)

Through participation in projects, contests, and so on, school administrations develop networks and coalitions which eventually help the school to informally influence education decisions and resource distribution. Another informal channel for schools' local and even regional influence is through influential parents of students, teachers (especially honoured teachers), or any prominent figure's participation in school activities (for example, war veterans participating in patriotic upbringing, sports champions invited to school competitions, or local business leaders invited to graduation events). Demonstrating high performance and creating local and regional visibility allows schools to attract powerful people to their informal networks.

The head of [the] city administration called me and reprimanded me: "Why do you solve your problems through veterans?" - but I didn't! We just invited this veteran, and he was in three wars, he is 96 years old, he met with Putin, we regularly invited him to school events, so he also wants to do something for us. He asks what we need, and we haven't yet got [good sports facilities]. 
Our observations in all three localities provided examples of schools with strong performance-based reputations which acted as "consultants" or "best practice providers" in their locality. In some cases, local education authorities delegated power to top-performing schools by making them official providers of expertise and advice (noted in all three countries).

The school that receives the bonus [for their high performance, in a scheme that is still under discussion] must, as ... compensation, offer some support, as ... [a] "sister school" to each school that hasn't been able to achieve the goal, in order to allow them to grow together.

(BR-S-01)

To be frank, our [school's] quality and standards ... have exceeded those required by the inspection and evaluation. I think the function [of inspectors] to "guide and supervise" is [less applicable] to us, unlike weak schools that are supervised and guided by education inspection. Schools like ours are more of an example and something to be exported.

(CN-S-01)

\section{Low-performing schools' room for action}

The interdependence of financial, human, and symbolic resources leads to a situation where school performance evaluation results sustain a virtuous cycle of resource accumulation for high-performing schools and a vicious cycle for low performers, who are increasingly disadvantaged because of their students' poor results. Teachers in these schools cannot improve their qualifications, as they have few if any high-performing students. Hence, it is harder for schools to attract new teachers, not only because career opportunities are bleak but because work itself can be more demanding and less emotionally rewarding. There are also fewer opportunities to win in contests; in some cases, schools cannot even apply if their previous performance is poor.

It can be so that a teacher does not participate in any contests, but can explain well, is a good teacher ... I wish they would abolish those [performance-based principles of calculating] salaries, they only provoke conflict. Or ... [define] criteria in a different way, or ... give it to the school, so that we could ourselves evaluate our teachers.

(RU-S-2)

Implementation of QAE procedures is regulated, so schools have no option but to comply with them.

As for the documents [regulations] coming from above, some of them are very concrete, they are very comprehensive, for example, there are over forty items in the students' quality education regulations for school 
operations pushed forward by the province level. We cannot violate [any] of them, otherwise there will be punishments [for] us.

(CN-S-06)

Once every three years we have inspections, you know, [to see] whether we work in accordance with the licence, with the accreditation.

If our institution somehow violates some norms, we may lose our accreditation, we may lose our licence. Hence all these monitoring studies [monitoringi], self-evaluation reports, all these different reports [exist] - all this is just so that the institution works as it should work by law.

(RU-S-2)

Complying with regulations and government priorities, as well as improving numerically measured performance, carries high stakes even for well-established schools. The Brazilian data provided an example of how a supervising authority restricted resource access to a medium-performing school because it was pursuing its own principles in managing education (retaining low-performing students and those who did not reach the minimum required school attendance).

I had to go to the Education Secretariat in the evening . . . to take the documentation, a process of around two or three hundred pages, to prove we did it right ... I was, in some way, harassed during the meeting to override teachers' decisions . . . to change the results of the teachers' meeting that retained around thirty students ... under the allegation that this [retention of students] would lower the school index [IDEB] . . . With an intimidating speech [they said] "If you have any projects going on at school and the IDEB is [ongoing], and you are retaining students and the IDEB decreases .... we will end ... all these projects, we will close your labs.

(BR-MS-1)

While this Brazilian school openly resisted new evaluation policy and confronted the authorities, in China and Russia, we witnessed no example of schools refusing to comply with QAE policies or openly questioning them. However, evaluations may be resisted in hidden ways; in both Brazil and Russia, our respondents mentioned that evaluation results could be fabricated and that it was to some extent possible to retain traditional practices while formally implementing new regulations.

I believe it is illusory to think that there is total control through the [external] evaluations. Lots of schools and teachers find ways to manipulate the dynamics, including making the evaluation look better than what ... the students answered .... in the evaluation. 


\section{Conclusion}

A comparative study of local practice in Brazil, China, and Russia reveals that local governance through QAE is more multifaceted in all three countries than is nationally envisioned. The enacted QAE policies and their effects on schools do not stay within the limits outlined by policymakers. QAE instruments, such as large-scale assessments, and the data they produce are reinterpreted locally in accordance with existing practices of quality control and school governance and are biased towards the political interests of local actors who seek resources and power. The opening or restriction of political opportunities for schools therefore also seem to differ from national policies' original intentions. We demonstrate that a combination of governance theories, rather than one theory, is needed to understand the diverse ways in which QAE policies can enhance and change local governance. We also argue that the study of schools' political room for action constitutes an important dimension in the investigation of local policy effects.

We identify several ways in which local education authorities can use QAE for governance. First, by evaluating schools and training them to work with data, local authorities seek to change internal school processes, make schools set specific goals, and focus on problems they have identified. They also anticipate that schools will adopt a new regime of constant self-improvement and an evaluation culture and that teachers and administrators will inform themselves in new ways (by collecting and processing quantitative data) about students' learning gaps. Such aspirations are representative of governance at a distance, which aims to change subjects' behaviour through constant surveillance and their "voluntarily" committing to act in accordance with government designs.

Local authorities also use evaluation in connection with traditional control measures (inspections, restrictions, fines, appointing and dismissing school administrations) to justify political decisions. QAE thus reinforces authorities' control over schools. Evaluation also provides the ground for resource distribution (financial, material, and human) and access to rewards: performance-based funding and salaries, higher qualifications, and prestigious status. The provision of incentives to comply with new regulations, while allowing subjects a degree of operational freedom, characterises a governance model based on new public management. We found that some schools' local governance QAE practices could be viewed as "micro-level NPM", while QAE mechanisms shifted responsibility for quality from local authorities to schools.

In these ways, QAE policies can enhance traditional governance instruments, create new connections between implementation of regulations and provision of resources, and facilitate greater access to schools' internal processes, formalising them and subjecting them to authorities' control. QAE tools can also help local authorities to demonstrate their own efficiency in supervising organisations, to be accountable to the public, and to change interactions between schools, authorities, and the community. 
Brazilian, Chinese, and Russian schools are implementing QAE policies to comply with national and sub-national legislation and as a response to the governance measures we have described. Compliance with QAE policies opens exclusive access to various resources and powers to high-performing schools. Apart from utilising the "official" schemes of resource accumulation (per capita funding, performance-based salaries, improving teacher qualifications), schools may find ways to use QAE instruments to attract additional resources from students and parents. Improved visibility through participation in contests and rankings allows schools to assume new roles as experts and providers of best practice and to attract affluent people to their networks and thus increase their local influence, which facilitates further accumulation of resources. Reputation occupies a central position in our analysis because it functions as both a symbolic resource and a source of power. We observe that reputation is key to virtuous (in the case of high-performing schools) or vicious (in the case of lowperforming schools) cycles in which schools find themselves ensnared when schemes involving performance-based funding and salaries are implemented. In some cases, the schools we analysed also embraced QAE policies as a helpful tool for quality improvement and internal management.

The room for action of the schools which opposed new QAE policies appeared limited in our research results. Some schools resisted QAE policies because they contradicted the school's educational goals (for example, the Brazilian school which insisted on retaining students) and faced the consequences, while others made no attempt at resistance even when they disagreed with policies, because they were governed by national regulations. The multiple governance tools of local authorities appeared effective in enforcing QAE policies in all the schools we observed. However, we also observed that schools could practise hidden resistance and to a certain extent avoid QAE tools' penetration of schools' internal processes.

In revealing the different mechanisms of QAE policies' local influence, our findings raise questions for further investigation. How typical of these and other localities are the effects we observed? What conditions authorities' and schools' selection of specific mechanisms? How are relations between local education actors influenced by broader contexts, for example, by local authorities' degree of autonomy from national and sub-national government and that of schools from different levels of government, or by national and local governance legacies? Who benefits from QAE policies in different situations? Answers to these questions and more would greatly enrich the understanding of local education governance through QAE.

\section{Bibliography}

Ball, S. J. (1993). Education policy, power relations and teachers' work. British Journal of Educational Studies, 41(2), 106-121.

Ball, S. J., Maguire, M., Braun, A., \& Hoskins, K. (2011). Policy actors: Doing policy work in schools. Discourse: Studies in the Cultural Politics of Education, 32(4), 625-639. 
Ball, S. J., \& Maroy, C. (2009). School's logics of action as mediation and compromise between internal dynamics and external constraints and pressures. Compare: A Journal of Comparative and International Education, 39(1), 99-112.

Bauer, A., Pimenta, C. O., Horta Neto, J. L., \& Sousa, S. Z. L. (2015). Avaliação em larga escala em municípios brasileiros: o que dizem os números? Estudios em Avaliação Educacional, 26(62), 326-352.

Bochenkov, S. (2013). Uchitel', shkola, sistema obrazovaniia v zerkale EGE [Teacher, school, system of education in the mirror of the USE]. Problemy sovremennogo obrazovaniia, 3, 27-47.

Bolman, L. G., \& Deal, T. E. (2013). Reframing Organizations: Artistry, Choice, and Leadership. Chichester: John Wiley \& Sons.

Bolotov, V. (2004). EGE: Promezhutochnie itogi [USE: Interim results]. Voprosy obrazovaniia, 2, 155-167.

Bourdieu, P. (1984 [1979]). Distinction: A Social Critique of the Judgement of Taste. Cambridge, MA: Harvard University Press.

Bourdieu, P. (1998 [1994]). Practical Reason: On the Theory of Action. Stanford: Stanford University Press.

Bourdieu, P. (2013 [1980]). O Senso Prático (3rd ed.). Petrópolis, RJ: Vozes.

Brasil. (1988). Constituição da República Federativa do Brasil [Constitution of the Federal Republic of Brazill. Brasília, DF: Senado Federal.

Brasil. (1996). Lei $n^{\circ}$ 9.394, de 20 de dezembro de 1996. Lei das diretrizes e bases da educação nacional [Law on the guidelines of national education] (LDBEN). Diário Oficial da República Federativa do Brasil, Brasília, DF, n. 248, 27.833-827.841, 24 dez.

Brasil. (2007). Decreto n. 6.094, de 24 de abril de 2007. Dispõe sobre a implementação do Plano de Metas Compromisso Todos pela Educação. Retrieved April 12, 2016, from www.planalto.gov. br/ccivil_03/_ato2007-2010/2007/decreto/d6094.htm

Brasil. (2014). Lei n. 13.005, de 25 de junho de 2014. Aprova o Plano Nacional de EducaçãoPNE e dá outras providências. Retrieved April 12,2016, www.planalto.gov.br/ccivil_03/_ato 2011-2014/2014/lei/113005.htm

Braun, A., Ball, S. J., Maguire, M., \& Hoskins, K. (2011). Taking context seriously: Towards explaining policy enactments in the secondary school. Discourse: Studies in the Cultural Politics of Education, 32(4), 585-596.

Braun, A., Maguire, M., \& Ball, S. J. (2010). Policy enactments in the UK secondary school: Examining policy, practice and school positioning. Journal of Education Policy, 25(4), 547-560.

Brooke, N. P., Cunha, M. A., \& Faleiros, M. (2011). A avaliação externa como instrumento da gestão educacional nos estados: relatório final. Belo Horizonte: Game/UFMG; Fundação Victor Civita.

Falabella, A. (2014). The performing school: The effects of market \& accountability policies. Education Policy Analysis Archives, 22(70).

Gunter, H. M., Grimaldi, E., Hall, D., \& Serpieri, R. (Eds.). (2016). New Public Management and the Reform of Education: European Lessons for Policy and Practice. London: Routledge.

Hood, C., \& Jackson, M. (1991). Administrative Argument. Aldershot: Dartmouth.

INEP. (2016). SAEB. ANEB e ANRESC (Prova Brasil). Retrieved June 10, 2016, from http:// portal.inep.gov.br/web/saeb/aneb-e-anresc

Kauko, J. (2013). Dynamics in higher education politics: A theoretical model. Higher Education, 65(2), 193-206.

Kauko, J., Simola, H., Varjo, J., \& Kalalahti, M. (2012). What could a dynamics perspective contribute to comparative research? In J. Kivirauma, A. Jauhianen, P. Seppänen, \& T. Kaunisto (Eds.), Koulutuksen yhteiskunnallinen ymmärrys [Social Perspectives on Education] (pp. 219-233). Turku: Finnish Educational Research Association. 
Kickert, W. (1995). Steering at a distance: A new paradigm of public governance in Dutch higher education. Governance: An International Journal of Policy and Administration, 8(1), 135-157.

Latour, B. (1987). Science in Action. Cambridge, MA: Harvard University Press.

Lawn, M., \& Grek, S. (2012). Europeanizing Education: Governing a New Policy Space. Oxford: Symposium Books.

Lingard, B., Martino, W., Rezai-Rashti, G., \& Sellar, S. (2016). Globalizing Educational Accountabilities. New York, NY: Routledge.

Machado, C., \& Alavarse, O. M. (2014). School quality: Impacts and challenges of external evaluation. Educação \& Realidade, 39(2), 413-436.

Maguire, M., Braun, A., \& Ball, S. J. (2015). "Where you stand depends on where you sit": The social construction of policy enactments in the (English) secondary school. Discourse: Studies in the Cultural Politics of Education, 36(4), 485-499.

Maroy, C. (2008). The new regulation forms of educational systems in Europe: Towards a post-Bureaucratic regime. In N. C. Soguel \& P. Jaccard (Eds.), Governance and Performance of Education Systems (pp. 13-33). The Netherlands: Springer.

Miller, P., \& Rose, N. (1990). Governing economic life. Economy and Society, 19(1), 1-31.

NAEQ. (2015). 基础教育质量监测信息简报 [Brief Report on Works of National Assessment of Education Quality]. Retrieved August 20, 2016, from www.eachina.org.cn.

Nóvoa, A., \& Yariv-Mashal, T. (2003). Comparative research in education: A mode of governance or a historical journey? Comparative Education, 39(4), 423-438.

Osborne, D., \& Gaebler, T. (1993). Reinventing Government: How the Entrepreneurial Spirit Is Transforming the Public Sector. Reading, MA: Addison-Wesley.

Ozga, J., Dahler-Larsen, P., Segerholm, C., \& Simola, H. (Eds.). (2011). Fabricating Quality in Education: Data and Governance in Europe. London: Routledge.

Piattoeva, N. (2015). Elastic numbers: National examinations data as a technology of government. Journal of Education Policy, 30(3), 316-334.

Pinto, L. (2000). Pierre Bourdieu e a Teoria do Mundo Social. Rio de Janeiro: FGV.

State Council. (2010). Guidelines of National Medium- and Long-Term Educational Reforms 2010-2020. Beijing: Ministry of Education. [Original in Chinese].

Tyack, D., \& Cuban, L. (1995). Tinkering Toward Utopia: A Century of Public School Reform. Cambridge, MA \& London: Harvard University Press.

Weber, M. (1949 [1904]). Objectivity in social science and social policy. In E. A. Shils, A. Edward, \& H. A. Finch (Eds.), Max Weber on the Methodology of the Social Sciences. Glencoe, IL: Free Press.

Weber, M. (2015 [1921]). Bureaucracy. In T. Waters \& D. Waters (Eds.), Weber's Rationalism and Modern Society: New Translations on Politics, Bureaucracy, and Social Stratification (pp. 73-127). London: Palgrave Macmillan. 